\title{
EPSL
}

Earth and Planetary Science Letters 124 (1994) 251-252

\section{Reply to Comment on "A critical re-evaluation of the Miocene/Pliocene boundary as defined in the Mediterranean" by R.H. Benson and D.A. Hodell}

\author{
F.J. Hilgen ${ }^{a}$, C.G. Langereis ${ }^{b}$ \\ ${ }^{a}$ Department of Geology, Institute of Earth Sciences, Budapestlaan 4, 3584 CD Utrecht, The Netherlands \\ ${ }^{b}$ Paleomagnetic Laboratory, Fort Hoofddijk, Budapestlaan 17, 3584 CD Utrecht, The Netherlands
}

(Received April 6, 1994)

In our reply to the comment of Benson and Hodell, we refrain from repeating the extensive discussion about the suitability and historical vindication of potential Miocene/Pliocene (M/P) boundary definitions. The various arguments have been dealt with both in our paper [1] as well as in Benson and Hodell's comment. However, we would like to take the opportunity to discuss some relevant points.

First and foremost, we would like to emphasise that we have never argued that recognizing the $\mathrm{M} / \mathrm{P}$ boundary outside the type area should be solely based on a cyclostratigraphic approach; that is the 5th precession-controlled sedimentary cycle below the lower Thvera reversal boundary. We have argued that the position of the boundary should be fit into a global cyclostratigraphic framework that is astronomically dated and which has a multiple biostratigraphy, magnetostratigraphy and isotope stratigraphy directly tied to it.

In their comment, Benson and Hodell take the position that epoch boundaries are not necessarily coincidental with stage boundaries and, as a consequence, that epoch boundaries can be de-

[PT] fined independently from existing stage boundaries. This point of view provides the means for relocating the Miocene/Pliocene ( $\mathrm{M} / \mathrm{P})$ boundary, from its current, and widely accepted, position at the base of the Zanclean Stage to the Gilbert / Chron 5 boundary, as proposed by Benson et al. [2]. The main argument for this proposal is the supposedly limited recognizability of the current boundary away from its stratotype, in particular in the extra-Mediterranean realm. As also put forward by Benson et al. [2], biostratigraphic recognition of the current boundary is, indeed, rather poor. However, the same is also true for the Moroccan alternative proposed by them because useful biohorizons in the Moroccan sequence are not closely associated with the Gilbert/Chron 5 reversal, but preceed it by 0.2 to more than $1.0 \mathrm{Myr}$. Thus, the main point of discussion is whether the potential short-comings of the current boundary warrrant a drastic redefinition, and the inconvenience arising from it. Needless to say, stability of the chronostratigraphic scale is an imperative need for the Earth Sciences and should be preferred unless there are serious reasons for abandoning existing or generally accepted boundary definitions.

Benson et al. [2] propose redefining the $\mathrm{M} / \mathrm{P}$

0012-821X/94/\$07.00 (C) 1994 Elsevier Science B.V. All rights reserved

SSDI 0012-821X(94)00076-B 
boundary at the Gilbert/Chron 5 boundary, because this would facilitate world-wide recognition. But the current boundary is already positioned very close to the next younger (lower Thvera) reversal boundary, which can as easily be identified. As a consequence, the position of the boundary away from the type section can be accurately determined from downward extrapolation of the Thvera sedimentation rate over a short interval of time $(100,000 \mathrm{yr} !)$.

Another aspect is that magnetostratigraphy is not routinely applied as a stratigraphic tool and, when applied, the results cannot always be interpreted straightforwardly. In quite a number of cases it is not possible to determine reliable paleomagnetic directions; for example, because of unsuitable sediments, remagnetisation and overprinting through weathering, and (early) diagenetic precipitation and dissolution of magnetic minerals. In this respect, the current choice of the $\mathrm{M} / \mathrm{P}$ boundary was unexpectedly fortunate because of the subsequently proven magnetostratigraphic suitability of the Trubi marls $[1,3,4]$. The magnetostratigraphic results of the composite Bou Regreg section, however, are not yet published; only for the Ain el Beida section is a magnetic inclination record given [in 5], but this record docs not encompass the Chron 5/Gilbert boundary. Moreover, interpreting the available Moroccan inclination data in terms of polarity is not unambiguous and the polarity sequence of Benson et al. [5] differs substantially from that of Krijgsman et al. [6] for the same interval on Crete.

Instead of aiming at a drastic rcdefinition, a more constructive approach to the $\mathrm{M} / \mathrm{P}$ boundary issue would be to determine the exact position of the current boundary-using an astronomically dated global cyclostratigraphic framework-both in the open ocean as well as in the Moroccan sequence and evaluate which useful (i.e., globally or regionally synchronous) biohori- zons are closely associated with the boundary. It will then become evident whether the prominent changes in neogloboquadrinid coiling about the $\mathrm{M} / \mathrm{P}$ boundary on Sicily are biostratigraphically significant. At the same time, locating exactly the same chronostratigraphic level in the Moroccan sequence would eliminate some formal, though less serious, objections against the Mediterranean $\mathrm{M} / \mathrm{P}$ boundary definition ( $\mathrm{a}$ discontinuous open marine succession and, at Capo Rossello, unconformity bounded). Following this approach, the option to define the actual boundary stratotype at Eraclea Minoa and a boundary parastratotype in Morocco should be seriously considered.

In summary, there is, according to us, at present no urgent need for a redefinition of the $\mathrm{M} / \mathrm{P}$ boundary as proposed by Benson and co-workers, because, in practise, the current boundary definition can be satisfactorily applied.

\section{References}

[1] F.J. Hilgen and C.G. Langereis, A critical re-evaluation of the Miocene/Pliocene boundary as defined in the Mediterranean, Earth Planet. Sci. Lett. 118, 167-179, 1993.

[2] R.H. Benson, K. Rakic-El Bied, G. Bonaduce, D.A. Hodell, W.A. Berggren, M.-P. Aubry, G. Napoleone and D.V. Kent, A proposal for the Pliocene global boundary stratotype and point: Bou Regreg, Morocco, IX RCMNS Congr., Barcelona, Abstr. Vol., p. 57, 1990.

[3] F.J. Hilgen and C.G. Langereis, The age of the MiocenePliocene boundary in the Capo Rossello area (Sicily), Earth Planet. Sci. Lett. 91, 214-222, 19.

[4] C.G. Langereis and F.J. Hilgen, The Rossello composite: A Mediterranean and global reference section for the Early to early Late Pliocene, Earth Planet. Sci. Lett., 104, 211-225, 1991.

[5] R.H. Benson, K. Rakic-El Bied and G. Bonaduce, An important current reversal (influx) in the Rifian Corridor (Morocco) at the Tortonian-Messinian boundary: The end of Tethys Ocean, Paleoceanography 6, 164 192, 1991.

[6] W. Krijgsman, F.J. Hilgen, C.G. Langereis and W.J. Zachariasse, The age of the Tortonian/Messinian boundary, Earth Planet. Sci. Lett. 121, 533-547, 1994. 